\title{
Mother's Ability to Massage her Baby with Technical Guidance from Medical Personnel: A Systematic Review
}

\author{
Ayatullah Harun ${ }^{1,2 *}$ (D), Andi Ummu Salmah ${ }^{3}$, Healthy Hidayanty ${ }^{4}$, Suriah Suriah ${ }^{5}$, Muhammad Syafar ${ }^{5}$, Veni Hadju ${ }^{4}$ \\ Muh. Tahir Abdullah ${ }^{3}$ \\ ${ }^{1}$ Doctoral Program in Public Health, Graduate School, Universitas Hasanuddin Makassar, South Sulawesi, Indonesia; ${ }^{2}$ Department \\ of Midwifery, Pelamonia, Institute of Health Sciences Kesdam XIV/Hasanuddin Makassar, South Sulawesi, Indonesia; ${ }^{3}$ Department \\ of Biostatistics/Population Family Planning, Faculty of Public Health, Universitas Hasanuddin, Makassar, South Sulawesi, \\ Indonesia; ${ }^{4}$ Department of Nutrition, Faculty of Public Health, Universitas Hasanuddin Makassar, South Sulawesi, Indonesia; \\ ${ }^{5}$ Department of Health Promotion, Faculty of Public Health, Universitas Hasanuddin, Makassar, South Sulawesi, Indonesia
}

Edited by: Eli Djulejic Citation: Harun A, Salmah AU, Hidayanty H, Suria S, Safar M, Hadju V, Abdullah MT. Mother's Ability to Massage Her Baby with Technical Guidance from Medica Personnel: A Systematic Review. Open-Access Maced Med Sci. 2021 Dec 12; 9(F): 747-752. Keywords: Babies; Premature; Low birth weight Keywords: Babies; Premature; Low birth weigh *Correspondence: Ayatullah Harun, Doctoral Program in Public Health, Graduate School, Universitas Hasanuddin Makassar, South Sulawesi, Indonesia. E-mail: haruna19k@student.unhas.ac.id Received: 20-Oct-2021
Revised: 26-Nov-2021 Accepted: 02-Dec-2021
Copyright: $\odot 2021$ Ayatullah Harun, Andi Ummu Salmah Healthy Hidayanty, Suriah Suriah, Muhammad Syafa, Veni Hadju, Muh Tahir Abdula Funding: This research did not receive any financial Competing Interests: The authors have declared that no competing interests exist Open Access: This is an open-access article distributed under the terms of the Creative Commons AttributionNonCommercial 4.0 International License (CC BY-NC 4.0)

\begin{abstract}
BACKGROUND: Baby spa is useful for baby's growth and development. The previous research has shown that when the baby is massaged by the mother, a bond is formed between the mother and the baby compared to othe people who do the massage. However, in its implementation, baby spas are often carried out by health workers.

AIM: The purpose of this research is to determine the mother's ability to do baby massage with the guidance of medical personnel.

METHODS: This method of writing systematic reviews refers to the Preferred Reporting Items for Systematic Reviews guidelines. Articles were searched in several databases ; ScienceDirect, EBSCO, PubMed, Scinapse Google Scholar from 2011-2021. The search strategy uses the keywords Infant OR Infant Preterm OR Very Low Birth Weight infants AND Massage OR Oil Massage AND Attachment AND Growth

RESULTS: The results show the chances of success of mothers doing baby massage with the help of medical personnel, the baby massage learning media used were baby phantoms, brochures, pamphlets, and baby massage videos, and the frequency of massage for 10-15 min each time the massage. The results obtained after the mother did the baby massage were the increase in body weight, body length, arm circumference of the baby, better bonding between mother and baby, improvement in mother's mood, and increase in mother's positive attitude in caring for the baby.

CONCLUSION: This study proves that the role of medical personnel in training baby massage to mothers is proven to be effective in increasing the ability of mothers to do baby massage.
\end{abstract}

\section{Introduction}

Babies are children with an age range of 0-12 months [1]. At this time, there is a rapid growth so that it is a good opportunity for parents to strive for optimal baby growth [2]. The first 1000 days of life - the time span roughly between conception and a person's second birthday - are a unique period of opportunity when the foundations for optimal health, growth, and neurodevelopment across the entire life span are laid [3]. Millions of children fail to fulfill their developmental potential and suffer mental health problems globally. Evidence is mixed as to whether growth after the first 1000 days of life affects intellectual function and mental health in school-age children [4].

Developmental delays are common in childhood, occurring in $10-15 \%$ of preschool children. Global developmental delays are less common, occurring in $1-3 \%$ of preschool children. Developmental delays are identified during routine check-ups by primary care physicians or when parents or preschoolers raise concerns [5]. The first 5 years of a child's life is a golden period of their development, contributing to their future learning skills and social and emotional abilities due to rapid progress in physical and development [6]. Infant sleep has dynamic trajectory, developmental changes that occur during this period, and interactions with other developmental domains [7]. Adequate sleep quantity and good sleep quality are associated with positive characteristics of children, which further underline their importance in promoting well-being in children [8]. To support growth, baby massage is carried out. Massage is effective manner to improve sleep quality, gross and fine motor development, in infants aged 3-6 months [9].

Baby massage has many benefits for baby's growth such as increasing baby's weight, body 
length, arm circumference, baby's sleep quality, decreasing bilirubin levels, reducing mother's stress level in caring for babies, and forging bonds between parents and babies [10], [11], [12], [13], [14], [15], [16], [17], [18], [19]. It is hoped that baby massage can be one of the routine care interventions that can be carried out by mothers [20], [21]. Massage that is done regularly on babies is used to massage the legs, abdomen, chest, hands, back, and stretching movements can increase baby's weight. Massage triggers a nerve action potential that stimulates the vagus nerve [22].

Some research on infant massage is currently still dominated by medical personnel such as midwives, nurses, and therapists [23], [24], [25]. The role of health workers is to provide education and practice baby massage for mothers to stimulate the growth and development of infants. This intervention can be integrated with maternal and child health programs in primary health-care facilities [26]. The low knowledge of mothers about the benefits of baby massage is one of the things that make a mother unable to do baby massage [20]. Research has shown that when the baby is massaged by the mother, a bond is formed between the mother and the baby compared to other people who do the massage [11], [14], [16]. Baby massage is very appropriate to be one form of pattern of care for babies that can be done by parents [20].

Mothers were instructed in breastfeeding by nurses or midwives but sometimes they did not receive infant massage education at the hospital where the study was conducted. Infant massage is a simple, inexpensive, and effective technique for supporting infant growth and development. It is accepted as a new practice which is gradually gaining popularity by being applied to babies and their mothers; it can be done independently. However, many mothers do not know that they can communicate with their babies by touch because they think that they can easily injure their babies. The mothers should be instructed to use various interactive methods such as touch, visual, and auditory contact. The nurse has a responsibility not only for the initiation of the mother's attachment to the infant but also for its maintenance. This is especially true for mothers who are very young and primiparous and who may need more support [14]. The use of baby spa requires coordination between the midwife and other health workers. Midwives must also provide health education about baby spa to stimulate baby's growth and development so that babies can grow optimally [27].

Based on this background, this study systematically reviews the mother's ability to perform infant massage with the guidance of medical personnel. This research is useful in supporting evidence of infant massage training by medical personnel if good results are obtained while maximizing the role of parents independently in managing and monitoring the health of their children.

\section{Methods}

\section{Study design and search strategy}

The writing of systematic reviews refers to the Preferred Reporting Items for Systematic Reviews guidelines. The search strategy for this systematic review is to identify articles that are relevant to the purpose of the study using five search databases. The five databases and keywords used, as shown in Table 1. These five databases are used as search engines to find articles that qualify for review. Some of the articles found from the database include ScienceDirect (28 articles), EBSCO (20 articles), PubMed (58 articles), Scinapse (38 articles), and Google Scholar (86 articles). Total number of articles is 230 articles.

Table 1: Search strategy and study selection criteria

\begin{tabular}{|c|c|}
\hline \multicolumn{2}{|l|}{ Search strategy } \\
\hline Database & Search strategy \\
\hline ScienceDirect, EBSCO, PubMed, Scinapse, and Google & Infant OR Infant Preterm \\
\hline Scholar & $\begin{array}{l}\text { OR Very low birth weight } \\
\text { infants AND Massage OR Oil } \\
\text { Massage AND Attachment } \\
\text { AND Growth }\end{array}$ \\
\hline \multicolumn{2}{|l|}{ Study selection criteria } \\
\hline Inclusion criteria & Exclusion criteria \\
\hline $\begin{array}{l}\text { English articles from } 2011 \text { to } 2021 \\
\text { Baby massage is done by the mother with the guidance } \\
\text { of medical personnel } \\
\text { Massage is performed on normal, premature and low } \\
\text { birth weight babies } \\
\text { There is data to know the baby massage learning media } \\
\text { used, the frequency of baby massage, and the output } \\
\text { produced after parents do baby massage }\end{array}$ & $\begin{array}{l}\text { Baby massage by medical } \\
\text { personnel } \\
\text { Articles that are not in English } \\
\text { Incomplete manuscript } \\
\text { regarding massage time and } \\
\text { massage amount }\end{array}$ \\
\hline
\end{tabular}

\section{Study selection, outcome measure, and data extraction}

The article extracted was first selected with inclusion and exclusion criteria. Inclusion and exclusion criteria data are described in Table 1. Assessment of article quality is carried out through the Joanna Briggs Institute Critical Appraisal Checklist. All systematic reviews incorporate a process of critique or assessment of research evidence. The purpose of this assessment is to assess the methodological quality of a study and to determine the extent to which a study has addressed possible biases in its design, behavior, and analysis. All papers selected for inclusion in the systematic review (i.e. - those that met the inclusion criteria described in the protocol) required rigorous assessment by two critical raters [28]. In this research, quality of article rated by seven authors. Non-conformance of the results resolved by discussion and consensus. 


\section{Data abstraction and synthesis}

Strategy search articles using the PICO method, $\mathrm{P}$ (Population) normal babies, premature babies, low birth weight babies (LBW). I (Intervention) baby massage, C (Comparison) skin-to-skin care, and O (Outcome) growth, bond between mother and baby. The data are then arranged in a table containing the author, year, sample, design, media, frequency, massage, and output/result.

The number of articles included in the review is 6 manuscripts, namely: (1) Gürol and Polat (2012), (2) Fallah et al. (2013), (3) Kumar et al. (2013), (4) Vicente et al. (2017), (5) Zhang and Wang (2019), and (6) Lotfalipour et al. (2019).

\section{Results}

The results of the systematic review were obtained from the study identification of 230 articles from database searches ScienceDirect $(n=28)$, EBSCO $(n=20)$, PubMed $(n=58)$, Scinapse $(n=38)$, and Google Scholar $(n=86)$, issued as many as 83 of the same articles, screened articles after duplication of 147 articles, issued articles after reading the title and abstract as many as 76 articles, and then read the full text of 71 articles and chose six articles whose massage was carried out by mothers with the guidance of medical personnel.

Table 2 shows the result of critical appraisal. All research shows that it has good qualities to be included in a systematic review.

The PRISMA results in Figure 1 show that after 230 articles screened, only 6 articles can be included in the criteria and continue the review process.

Table 3 shows the output of mother's ability to massage her baby with technical guidance from medical personnel.
Table 2: JBI critical appraisal checklist

\begin{tabular}{|c|c|c|c|c|c|c|}
\hline Criteria & 1 & 2 & 3 & 4 & 5 & 6 \\
\hline $\begin{array}{l}\text { Is it clear in the study what is the "cause" and what is the } \\
\text { "effect" (i.e., there is no confusion about which variable } \\
\text { comes first)? }\end{array}$ & $\mathrm{Y}$ & $\mathrm{Y}$ & $\mathrm{Y}$ & $\mathrm{Y}$ & $\mathrm{Y}$ & $\mathrm{Y}$ \\
\hline Were the participants included in any comparisons similar? & Y & $\mathrm{Y}$ & Y & $\mathrm{Y}$ & $\mathrm{Y}$ & $\mathrm{Y}$ \\
\hline $\begin{array}{l}\text { Were the participants included in any comparisons } \\
\text { receiving similar treatment/care, other than the exposure or } \\
\text { intervention of interest? }\end{array}$ & $\mathrm{Y}$ & $Y$ & Y & $Y$ & Y & $Y$ \\
\hline Was there a control group? & $\mathrm{Y}$ & $\mathrm{Y}$ & Y & $\mathrm{Y}$ & $\mathrm{Y}$ & $\mathrm{Y}$ \\
\hline $\begin{array}{l}\text { Were there multiple measurements of the outcome both pre } \\
\text { and post the intervention/exposure? }\end{array}$ & $\mathrm{Y}$ & $\mathrm{Y}$ & $\mathrm{Y}$ & $\mathrm{Y}$ & $\mathrm{Y}$ & $\mathrm{Y}$ \\
\hline $\begin{array}{l}\text { Was follow up complete and if not, were differences between } \\
\text { groups in terms of their follow up adequately described and } \\
\text { analyzed? }\end{array}$ & Y & $\mathrm{Y}$ & Y & $Y$ & Y & Y \\
\hline $\begin{array}{l}\text { Were the outcomes of participants included in any } \\
\text { comparisons measured in the same way? }\end{array}$ & $\mathrm{Y}$ & $\mathrm{Y}$ & Y & $\mathrm{Y}$ & $\mathrm{Y}$ & $\mathrm{Y}$ \\
\hline Were outcomes measured in a reliable way? & $\mathrm{Y}$ & $\mathrm{Y}$ & Y & $\mathrm{Y}$ & $\mathrm{Y}$ & $\mathrm{Y}$ \\
\hline Was appropriate statistical analysis used? & $\mathrm{Y}$ & $\mathrm{Y}$ & $\mathrm{Y}$ & $\mathrm{Y}$ & $\mathrm{Y}$ & $\mathrm{Y}$ \\
\hline
\end{tabular}

Assistance of medical personnel such as midwives, nurses, or other medical personnel in helping mothers does baby massage based on the synthesized articles, namely, medical personnel conducting baby massage training to mothers. Baby, one of the methods used, is by way of demonstration. Medical personnel directly practice how to do baby massage using baby phantom media. In addition to baby phantom media, medical personnel also provide printed media such as brochures and pamphlets and baby massage videos [10], [14], [15], [16].

The duration and duration of the baby massage intervention that can be done by parents based on the six articles analyzed, the average frequency of massage performed by mothers on their babies is 10-15 min each time they do massage [10], [14], [15], [16], [29], [30] which can be done at least once a day [14] or a maximum of 4 times a day [30] depending on the condition of the baby (normal, premature, and LBW). The results obtained after the mother did baby massage with the guidance of medical personnel, namely, the occurrence of weight gain [10], [29], [30], baby's body length and arm circumference [10], the occurrence of a better bond between parents and babies, as well as an increase in the mood of mothers who have premature babies [14]. Where from six

Table 3: The output of mother's ability to massage her baby with technical guidance from medical personnel

\begin{tabular}{|c|c|c|c|c|c|}
\hline Author (Year) & Sample & Design & Media & Massage frequency & Output/results \\
\hline Gürol and Polat (2012) [14] & $\begin{array}{l}117 \text { mothers who have normal babies } \\
\text { Intervention } 60 \text { mothers, Control } 57 \\
\text { mothers }\end{array}$ & $\begin{array}{l}\text { Quasi } \\
\text { experiment }\end{array}$ & $\begin{array}{l}\text { Baby phantoms, } \\
\text { baby massage } \\
\text { videos, brochures }\end{array}$ & $\begin{array}{l}15 \text { min daily for } 38 \\
\text { Days }\end{array}$ & $\begin{array}{l}\text { The bond between mother and baby in the } \\
\text { intervention pre-test value } 88.12 \pm 15.19 \text {, post-test } \\
\text { value } 90.87 \pm 10.76 \text { with } p=0.01 \text { control pre-test } \\
\text { value } 84.28 \pm 17.60 \text { and post-test value } \\
85.10 \pm 15.50 p=0.36\end{array}$ \\
\hline Fallah et al. (2013) [29] & $\begin{array}{l}54 \text { premature babies with LBW } \\
\text { Intervention } 27 \text { babies, control } 27 \\
\text { babies }\end{array}$ & $\begin{array}{l}\text { Randomized } \\
\text { controlled trials }\end{array}$ & No data available & $\begin{array}{l}10 \text { min, } 3 \text { times a day, } \\
\text { morning, afternoon and } \\
\text { evening during } 14 \text { days }\end{array}$ & $\begin{array}{l}\text { Weight gain measurement in the } 1^{\text {st }} \text { month in the } \\
\text { intervention group }=2334 \pm 135 \\
\text { Control }=2201 \pm 93, p=0.04\end{array}$ \\
\hline Kumar et al. (2013) [30] & $\begin{array}{l}48 \text { premature babies with LBW, } 25 \\
\text { infant interventions, control } 25 \text { babies }\end{array}$ & $\begin{array}{l}\text { Randomized } \\
\text { controlled trials }\end{array}$ & No data available & $\begin{array}{l}10 \text { min } 4 \text { times a day, } \\
\text { for } 28 \text { days }\end{array}$ & $\begin{array}{l}\text { Weight gain in the intervention } \\
\text { group }=4761.7 \pm 47.9 \text { Control group }=334.9 \pm 46.4, \\
p=0.05\end{array}$ \\
\hline Vicente et al. (2017) [15] & $\begin{array}{l}194 \text { pairs of healthy mothers and } \\
\text { babies, intervention } 97 \text { mothers and } \\
\text { babies, controls } 97 \text { mothers and } \\
\text { babies }\end{array}$ & Experiment & Baby phantom & $\begin{array}{l}10-15 \text { min each } \\
\text { massage session until } \\
\text { baby is } 12 \text { months old }\end{array}$ & $\begin{array}{l}\text { There was a better bond between mother and } \\
\text { baby and mothers had more positive attitudes than } \\
\text { mothers in the control group }\end{array}$ \\
\hline Zhang and Wang (2019) [10] & $\begin{array}{l}112 \text { premature babies } \\
\text { Intervention } 52 \text { mothers, Control } \\
\text { group } 26 \text { mothers }\end{array}$ & Experiment & Baby spa video & $\begin{array}{l}15 \text { min, } 2 \text { times a day } \\
\text { for } 2 \text { weeks }\end{array}$ & $\begin{array}{l}\text { Weight gain, length/height, arm circumference } \\
F=41.151,6.621,24.158 \text {, respectively; } p<0.001 \text { ). }\end{array}$ \\
\hline Lotfalipour et al. (2019) [16] & $\begin{array}{l}52 \text { mothers with premature babies } \\
\text { Intervention } 52 \text { mothers, Control } 26 \\
\text { mothers }\end{array}$ & Experiment & $\begin{array}{l}\text { Baby phantoms, } \\
\text { pamphlets, baby } \\
\text { massage videos }\end{array}$ & 15 min daily for 5 days & $\begin{array}{l}\text { Maternal mood scores increased significantly in the } \\
\text { intervention group }(p<0.001) \text {, the control group } \\
(p=0.02)\end{array}$ \\
\hline
\end{tabular}


articles, two articles assessing weight gain [29], [30], one article assessing baby's weight gain, length, and arm circumference [10], one article assessing the bond between mother and baby [14], one article assessing mood improvement in mothers of premature babies [16], and one article assessing that there is a better bond between mother and baby and mothers have a more positive attitude in caring for babies than mothers who do not do baby massage [15].

\section{Discussion}

The guidance of medical personnel in helping mothers to do baby massage has been proven to be effective in increasing the mother's ability to do baby massage. The benefits obtained are equally effective when compared to baby spas carried out by healthcare personnel. In one study, infant massage appeared to be a viable option for teaching paternal parenting sensitivity. While reporting a brief intervention, the study showed that participating fathers were helped by increasing their feelings of competence, role acceptance, partner support, attachment, and health and by reducing feelings of isolation and depression. Baby massage classes seem to offer dads a positive experience to meet other dads and enjoy the opportunity to share their father's experiences [31]. Baby massage functions include strengthen and improve the interaction between children and adults so as to improve their health. This cost-saving technique can provide a simple but effective way to support early affective bonding; in this way, it can accompany the existing process and maintain the dyad during the expected developmental challenges, if necessary. Especially in complex intervals such as the postpartum period, this practice can be very important, as it can help couples deal with mutual adjustment needs, facilitating the process of regulation and establishment of the sleep-wake cycle. In addition, an emotionally intense "guided" approach to babies can reassure mothers, who often perceive newborns as fragile and afraid to touch them, making them more confident when holding their babies. From this perspective, infant massage is a valuable resource in terms of primary prevention, that is, in terms of interventions aimed at maintaining and enhancing existing resources in the family system, as it can be offered as enriching support also in the absence of adult psychopathology [32]. Parents all over the world have been massaging their babies for centuries. The popularity of baby massage in Western countries is a relatively recent phenomenon; the trend may have developed due to the perceived health benefits. In some Eastern cultures, the practice of baby massage is passed down from one generation to the next. In Western culture, new parents are more likely to attend a local baby massage class with an instructor.
Whatever the form of exercise, it is important to know that there is no potential to harm the baby [33].

One of the learning strategies carried out by medical personnel is to use more than 1 learning media, several studies in the intervention combine one media with another [14], [16]. For example, giving baby massage training interventions with baby phantoms, baby massage videos, and brochures [14]. Giving media more than $1 \mathrm{goal}$ is to make it easier for mothers to learn to do baby massage besides that every mother is different in understanding and liking a learning media, some are happy with reading, some are happy through hearing (audio), and some are happy with learning media only through videos. The ability to deliver messages for each media is different [34] so that medical personnel need to discuss with the mother before giving baby massage learning media. Women with a better level of empowerment will have a lower chance of experiencing infant mortality. Women's empowerment is associated with improved child nutrition, and both underpin the achievement of multiple sustainable development goals [35].

The ability of mothers to massage babies with the guidance of medical personnel has proven to be effective against weight gain in premature babies and LBW babies. Related to the baby's digestive function and hormones, such as gastrin and insulin [11],[25], [36], [37], baby massage can cause baby being hungry quickly and breastfeed more actively and more often. This will stimulate an increase in the secretion of the mother's prolactin and oxytocin hormones which will result in more milk being produced [20].

One of the benefits of baby massage that is done by the mother to her baby is the formation of a bond of affection between mother and baby. The gentle touch and loving gaze of a mother towards her child will be able to flow the strength of the inner bond between them [16]. This becomes the basis for children's growth and development in forming effective communication patterns. The formation of an effective communication pattern from an early age is a determinant in the formation of a child's character who is of good character and self-confidence. Baby massage that is done by the mother will further increase the bond that has been formed since the baby is still in the womb. Baby massage is an expression of love between mother and child through touching the skin which has a very extraordinary impact. Massaging the baby regularly is one way to build a bond with the baby which has an impact on the growth of a healthier baby and makes the mother feel happy and happy in taking care of the baby [15], [16], [38]. 


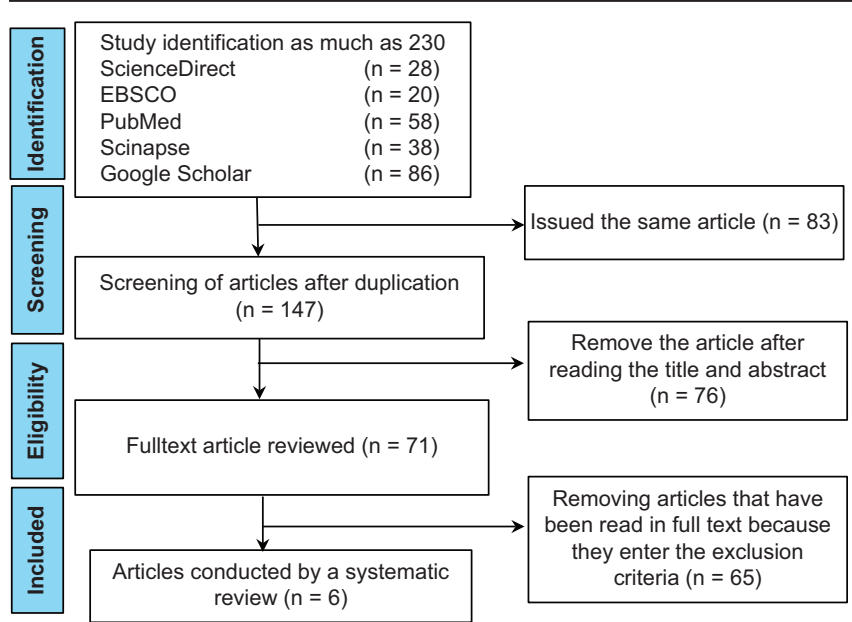

Figure 1: Preferred Reporting Items for Systematic Reviews flow diagram

These results indicate that the chances of mothers in giving massage to their babies. If the mother has health problems, this action has the opportunity to be carried out by the husband as a substitute [20], [39].

\section{Conclusion}

This study proves the role of medical personnel in teaching and training baby massage to mothers is proven to be effective in increasing the ability of mothers to massage babies using baby phantom media, videos, brochures, and pamphlets which have an impact on weight gain, bonding between mother and baby, mood enhancement mothers, as well as increasing the mother's positive attitude in caring for the baby.

\section{Acknowledgment}

Thank you to the supervising lecturer at the Faculty of Public Health, Universitas Hasanuddin Makassar.

\section{References}

1. Noorbaya S. Asuhan Neonatus Bayi, Balita dan Anak Prasekolah. United States: In Gosyen Publising; 2019.

2. Soetjiningsih. Tumbuh kembang anak. In: Kedokteran PB, editor. Buku Kedokteran EGC. Penerbit Buku Kedokteran. Tamil Nadu: EGC; 2013.

3. Cusick S, Georgieff MK. The First 1,000 Days of Life: The Brain's Window of Opportunity. United States: UNICEF; 2013. Available from: https://www.unicef-irc.org/article/958-the-first1000-days-of-life-the-brains-window-of-opportunity.html. [Last accessed on 2021 Oct 12].

4. Nguyen PH, Tran LM, Khuong LQ, Young MF, Duong TH, Nguyen $\mathrm{HC}$, et al. Child linear growth during and after the first 1000 days is positively associated with intellectual functioning and mental health in school-age children in Vietnam. J Nutr. 2021;151(9):2816-24. https://doi.org/10.1093/jn/nxab182 PMid:34113979

5. Choo YY, Agarwal P, How $\mathrm{CH}$, Yeleswarapu SP. Developmental delay: Identification and management at primary care level. Singapore Med J. 2019;60(3):119-23. https://doi.org/10.11622/ smedj.2019025

PMid:30997518

6. Butchon R, Liabsuetrakul T. The development and growth of children aged under 5 years in Northeastern Thailand: A crosssectional study. J Child Adolesc Behav. 2017;5:334.

7. Tham EK, Schneider N, Broekman BF. Infant sleep and its relation with cognition and growth: A narrative review. Nat Sci Sleep. 2017;9:135-49. https://doi.org/10.2147/NSS.S125992 PMid:28553151

8. Lemola S, Räikkönen $\mathrm{K}$, Scheier MF, Matthews KA Pesonen AK, Heinonen K, et al. Sleep quantity, quality and optimism in children. J Sleep Res. 2011;20(1):12-20. https://doi. org/10.1111/j.1365-2869.2010.00856.x PMid:20561178

9. Kusumastuti NA, Tamtomo D, Salimo H. Effect of massage on sleep quality and motor development in infant aged 3-6 months. J Matern Child Health. 2016;1(3):161-9.

10. Zhang $X$, Wang J. Massage intervention for preterm infants by their mothers: A randomized controlled trial. J Spec Pediatr Nurs. 2019;24(2):e12238.

11. Alizadeh P, Goudarzi Z, Shariat M, Nariman S. Infant behavior and development the effect of a short course of moderate pressure sunflower oil massage on the weight gain velocity and length of NICU stay in preterm infants. Infant Behav Dev. 2018;50:22-7. https://doi.org/10.1016/j.infbeh.2017.11.002 PMid:29126078

12. Saeidi R, Ghorbani Z, Moghadam AS. The Effect of Massage with Medium-Chain Triglyceride Oil on Weight Gain in Premature Neonates. 2014;18:2-6. PMid:25725185

13. Eghbalian $\mathrm{F}$, Rafienezhad $\mathrm{H}$, Farmal $\mathrm{J}$. The lowering of bilirubin levels in patients with neonatal jaundice using massage therapy: A randomized, double-blind clinical trial. Infant Behav Dev. 2017;49:31-6. https://doi.org/10.1016/j.infbeh.2017.05.002 PMid:28688960

14. Gürol A, Polat $S$. The effects of baby massage on attachment between mother and their infants. Asian Nurs Res (Korean Soc Nurs Sci). 2012;6(1):35-41. https://doi.org/10.1016/j. anr.2012.02.006 PMid:25030689

15. Vicente $\mathrm{S}$, Veríssimo M, Diniz E. Infant massage improves attitudes toward childbearing, maternal satisfaction and pleasure in parenting. Infant Behav Dev. 2017;49:114-9. https:// doi.org/10.1016/j.infbeh.2017.08.006 PMid:28866286

16. Lotfalipour B, Tirgari B, Pouraboli B, Mirzaee M. Effect of preterm infant massage by the mother on the mood of mothers having preterm infants. J Chiropr Med. 2019;18(1):67-76. https://doi. org/10.1016/j.jcm.2018.11.001 PMid:31193199

17. Serrano MS, Doren FM, Wilson L. Teaching chilean mothers to massage their full-term infants: Effects on maternal breastfeeding and infant weight gain at age 2 and 4 months. J Perinat Neonatal Nurs. 2010;24(2):172-81. https://doi.org/10.1097/ JPN.0b013e3181db5377 


\section{PMid:20442614}

18. Procianoy RS, Mendes EW, Silveira RC. Massage therapy improves neurodevelopment outcome at two years corrected age for very low birth weight infants. Early Hum Dev. 2010;86(1):711. https://doi.org/10.1016/j.earlhumdev.2009.12.001 PMid:20022717

19. Dalili H, Sheikhi S, Shariat M, Haghnazarian E. Effects of baby massage on neonatal jaundice in healthy Iranian infants: A pilot study. Infant Behav Dev. 2016;42:22-6. https://doi.org/10.1016/j. infbeh.2015.10.009

PMid:26646074

20. Utami R. Pedoman Pijat Bayi. Jakarta: In Pustaka Pembangunan Swadaya Nusantara; 2016.

21. Riksani RA. Cara Mudah dan Aman Pijat Bayi. Indonesia: Dunia Sehat; 2012.

22. Fatmawati N, Zulfiana $\mathrm{Y}$, Pratiwi $\mathrm{YS}$. The effect of baby massage on improvement baby weight. J Qual Public Health. 2021;4(2):227-32.

23. Moyer-Mileur LJ, Haley S, Slater H, Beachy J, Smith SL. Massage improves growth quality by decreasing body fat deposition in male preterm infants. J Pediatr. 2013;162(3):490-5. https://doi.org/10.1016/j.jpeds.2012.08.033

PMid:23062248

24. Choi H, Kim S, Oh J, Lee M, Kim S, Kang K. The effects of massage therapy on physical growth and gastrointestinal function in premature infants: A pilot study. J Child Health Care. 2016;20(3):394-404. https://doi. org/10.1177/1367493515598647 PMid:26311485

25. Ho Y, Lee RS, Chow C, Pang MY. Impact of massage therapy on motor outcomes in very low-birthweight infants : Randomized controlled pilot study. 2010;52(3):378-85. https:// doi.org/10.1111/j.1442-200X.2009.02964.x PMid:19761514

26. Lestari KP, Nurbadlina FR, Wagiyo W, Jauhar M. The effectiveness of baby massage in increasing infant's body weight. J Public Health Res. 2021;10:2332. https://doi. org/10.4081/jphr.2021.2332 PMid:34060735

27. Sudiro K, Mulyati S. Baby spa effect on growth. Asian J Appl Sci. 2018;6(5):5538. https://doi.org/10.24203/ajas.v6i5.5538

28. Institute TJ. Checklist for Quasi-experimental Studies. Australia: Joanna Briggs Institute; 2017. p. 1-6. Available from: http:// www.joannabriggs.org/assets/docs/critical-appraisal-tools/JBI Quasi-Experimental_Appraisal_Tool2017.pdf. [Last accessed on 2021 Oct 12].

29. Fallah R, Akhavan Karbasi S, Golestan M, Fromandi M. Sunflower oil versus no oil moderate pressure massage leads to greater increases in weight in preterm neonates who are low birth weight. Early Hum Dev. 2013;89(9):769-72. https://doi. org/10.1016/j.earlhumdev.2013.06.002

PMid:23830725

30. Kumar J, Upadhyay A, Dwivedi AK, Gothwal S, Jaiswal V, Aggarwal S. Effect of oil massage on growth in preterm neonates less than $1800 \mathrm{~g}$ : A randomized control trial. Indian J Pediatr. 2013;80(6):465-9. https://doi.org/10.1007/s12098-012-0869-7 PMid:23054851

31. Cheng CD, Volk AA, Marini ZA. Supporting fathering through infant massage. J Perinat Educ. 2011;20(4):200-9. https://doi. org/10.1891/1058-1243.20.4.200

PMid:22942622

32. Porreca A, Parolin M, Bozza G, Freato S, Simonelli A. Infant massage and quality of early mother-infant interactions: Are there associations with maternal psychological wellbeing, marital quality, and social support? Front Psychol. 2017;7:2049. https://doi.org/10.3389/fpsyg.2016.02049

PMid:28144222

33. Cooke A. Infant massage: The practice and evidence-base to support it. Br J Midwifery. 2015;23(3):166-70.

34. Kholid A. Promosi Kesehatan dengan Pendekatan Teori Perilaku, Media, dan Aplikasinya. Indonesia: PT. Raya Leuwinanggung Persada; 2012.

35. Jones R, Haardörfer R, Ramakrishnan U, Yount KM, Miedema S, Girard AW. Women's empowerment and child nutrition: The role of intrinsic agency. SSM Popul Health. 2019;9:100475. https:// doi.org/10.1016/j.ssmph.2019.100475

PMid:31993480

36. Badr LK, Abdallah B, Kahale L. A meta-analysis of preterm infant massage: An ancient practice with contemporary applications. MCN Am J Matern Nurs. 2015;40(6):344-58. https://doi. org/10.1097/NMC.0000000000000177 PMid:26302088

37. Álvarez MJ, Fernández D, Gómez-Salgado J, RodríguezGonzález D, Rosón M, Lapeña S. The effects of massage therapy in hospitalized preterm neonates: A systematic review. Int J Nurs Stud. 2017;69:119-36. https://doi.org/10.1016/j. ijnurstu.2017.02.009 PMid:28235686

38. Ribka L. Interventions to improve maternal-infant relationships in mothers with postpartum mood disorders. MCN. 2018;43(6):33440. https://doi.org/10.1097/NMC.0000000000000471 PMid:30339579

39. Suchy C, Morgan G, Duncan S, Villar S, Fox F, Rutledge DN Teaching father-infant massage during postpartum hospitalization. MCN Am J Matern Nurs. 2020;45(3):169-75. https://doi.org/10.1097/NMC.0000000000000613 PMid:32039984 